\title{
Glucagon-like peptide-1 but not glucagon-like peptide-2 stimulates insulin release from isolated rat pancreatic islets
}

\author{
W.E.Schmidt, E. G. Siegel and W.Creutzfeldt \\ Division of Gastroenterology and Metabolism, Department of Medicine, University of Göttingen, Göttingen, FRG
}

Summary. Glucagon-like peptide-1 and glucagon-like peptide- 2 are encoded by the m-RNA of pancreatic preproglucagon. They show high conservation in different species and substantial sequence homology to glucagon. Because no definite biological activity of these peptides has been reported, we investigated the effect of synthetic C-terminally amidated glucagon-like peptide-1 [1-36] and synthetic human glucagonlike peptide-2 [1-34] with a free C-terminus on insulin release from isolated precultured rat pancreatic islets in the presence of glucose. Glucagon-like peptide-1 stimulates insulin release at 10 and $16.7 \mathrm{mmol} / 1$ glucose in a dose-dependent manner. Significant stimulation starts at $2.5 \mathrm{nmol} / 1$ in the presence of $10 \mathrm{mmol} / 1$ glucose and near maximal release is observed at
$250 \mathrm{nmol} / 1$, with approximately $100 \%$ increase over basal at both glucose concentrations. The peptide reaches $63 \%$ of the maximal stimulatory effect of glucagon. No stimulation occurs in the presence of $2.8 \mathrm{mmol} / 1$ glucose. Glucagon-like peptide-2 has no effect on insulin secretion at any glucose concentration tested. It is concluded that glucagon-like peptide-1, in contrast to glucagon-like peptide-2, exhibits a glucose-dependent insulinotropic action on isolated rat pancreatic islets similar to that of glucagon and gastric inhibitory polypeptide.

Key words: Glucagon-like peptide-1, glucagon-like peptide-2, insulin release, glucose dependency, isolated islets.
Pancreatic preproglucagon m-RNA, the precursor of pancreatic glucagon, has been cloned and sequenced from different species using recombinant DNA-techniques [1-5]. Two other peptides have been found arranged in tandem on the same m-RNA in close proximity C-terminal to the glucagon precursor: glucagonlike peptide-1 (GLP-1) and glucagon-like peptide-2 (GLP-2) comprising 36 and 34 amino acid residues, respectively. Both peptides show a different degree of sequence homology to pancreatic glucagon. The GLP-1 sequence is identical in the human, bovine and hamster precursor, whereas minor differences exist between the corresponding GLP-2 sequences. This substantial conservation in evolution and the close sequence homology to the glucagon molecule (GLP-1: $48 \%$ identical residues; GLP-2: 38\%) indicates that GLP-1 and GLP-2 may play an important role of their own as hormones or local modulators. Recently they have been detected by specific radioimmunoassays in glucagonomas and in rat pancreatic islets [6], although they have not to date been isolated at the peptide level. Very little is known about a specific biological activity of these peptides. Hoosein and Gurd [7] could demonstrate a potent stimulation of rat hypothalamic and pituitary adenylate cyclase, whereas binding of glucagon to rat brain and liver membranes was not inhibited. GLP-1 may exert a weak stimulatory effect on exocrine pancreatic secretion in the rat [8].
Suggesting a role in carbohydrate metabolism, we investigated the effect of synthetic GLP-1 and GLP-2 on insulin release from isolated precultured rat pancreatic islets in the presence of glucose.

\section{Material and methods}

Pancreatic islets from fed male Wistar rats weighing 200-250g were isolated by collagenase digestion of the pancreas [9]. The islets were kept in tissue culture medium 199 [10] for $24 \mathrm{~h}$. This procedure in-

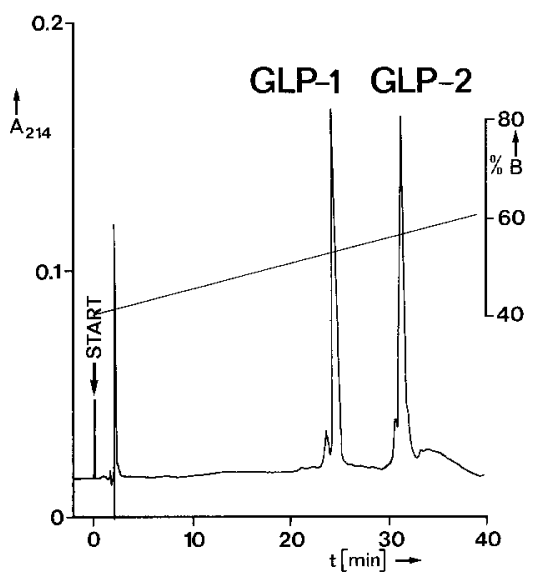

Fig. 1. HPLC-chromatogram of synthetic glucagon-like peptide-1 (GLP-1) and glucagon-like peptide-2 (GLP-2) (10 $\mu \mathrm{g}$ each, injected together) using the TFA/acetonitrile gradient system. Temperature: $40^{\circ} \mathrm{C}$; detection: $214 \mathrm{~nm}$, sensitivity: $0.2 \mathrm{AU}$; flow $1.5 \mathrm{ml} / \mathrm{min}$ 


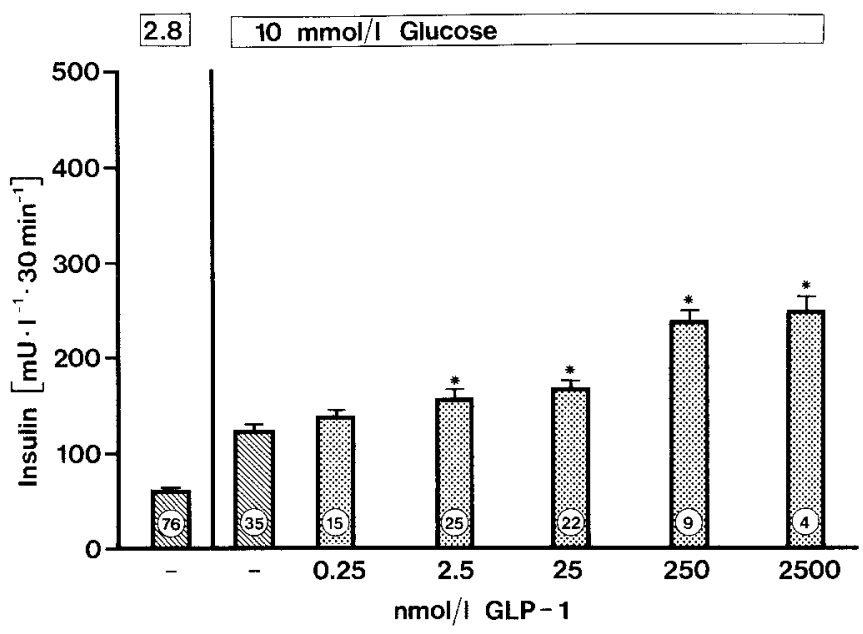

Fig. 2. Effect of glucagon-like peptide-1 on insulin release from isolated precultured rat pancreatic islets in the presence of $10 \mathrm{mmol} / 1$ glucose (right panel). For comparison basal release at $2.8 \mathrm{mmol} / 1 \mathrm{glu}-$ cose (left panel) is included; the number of experiments in each group is given in circle. $*=p<0.05$

\section{$2.8 \quad 16.7 \mathrm{mmol} / \mathrm{l}$ Glucose}

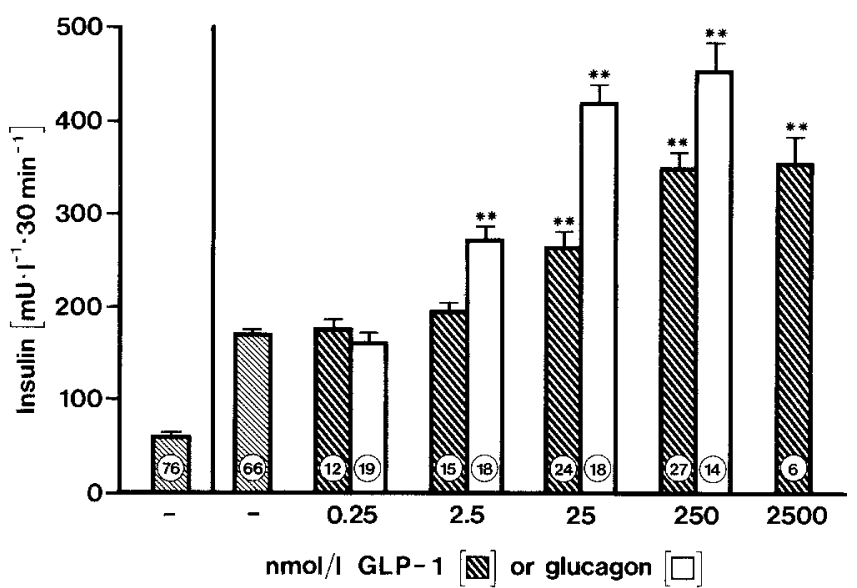

Fig. 3. Effect of glucagon-like peptide-1 (hatched bars) and glucagon (open bars) on insulin release from isolated precultured rat pancreatic islets in the presence of $16.7 \mathrm{mmol} / 1$ glucose (right panel). For comparison basal release at $2.8 \mathrm{mmol} / \mathrm{l}$ glucose (left panel) is included; the number of experiments in each group is given in circle; $* *=p<0.01$

creases markedly the hormone sensitivity of isolated islets [11]. Static incubations of 10 islets per vial were performed in $2 \mathrm{ml}$ oxigenized Krebs-Ringer Hepes buffer $\mathrm{pH} 7.4$ containing $0.2 \%(\mathrm{w} / \mathrm{v})$ bovine serum albumin and $1 \%(\mathrm{~W} / \mathrm{v})$ Hepes for $30 \mathrm{~min}$ in the presence of glucose at $2.8,10$ or $16.7 \mathrm{mmol} / 1$. Synthetic GLP-1 (1-36, C-term. :-ArgNH2) and GLP-2 (1-34, C-term.:-Arg-COOH, human sequence) (Peninsula Lab., Belmont, Calif., USA), were purified by high-performance liquid chromatography (HPLC) (Waters, Milford) on a reversed phase C-18 wide-pore column (Vydac RP 218) using a trifluoroacetic acid (TFA) / acetonitrile gradient system (buffer $\mathrm{A}: 0.1 \%$ TFA; buffer B: $0.1 \%$ TFA $/ 29.9 \%$ water $/ 70 \%$ acetonitrile). Islets were incubated with HPLC-pure peptides at concentrations of $0.25,2.5,25$, 250 and $2500 \mathrm{nmol} / 1$, respectively. Insulin release was measured by radioimmunoassay [12]. Results are expressed in $\mathrm{mU} \cdot 1^{-1} \cdot 30 \mathrm{~min}^{-1}$ as mean \pm SEM and were analyzed by the two-tailed Student's $t$-test for unpaired data adapted for multiple comparisons according to Holm [13]; $p<0.05$ was considered to be significant.

\section{Results}

The HPLC-chromatogram of GLP-1 and GLP-2 $(10 \mu \mathrm{g}$ each, injected together) is shown in Figure 1. To avoid side-effects of impurities, only the middle portions of the symmetrical HPLC-peaks were used in biological experiments. The purity of the HPLC-rechromatographed peptides was estimated better than $99.5 \%$. Figure 2 shows the effect of GLP-1 on insulin release from isolated precultured rat pancreatic islets in the presence of $10 \mathrm{mmol} / 1$ glucose and Figure 3 at $16.7 \mathrm{mmol} / 1$ glucose during a $30-\mathrm{min}$ static incubation. Without peptide the insulin release raised by $100 \%$ in the presence of $10 \mathrm{mmol} / \mathrm{l}$ glucose compared to $2.8 \mathrm{mmol} / 1$; another $50 \%$ increase was observed at $16.7 \mathrm{mmol} / 1$ glucose versus $10 \mathrm{mmol} / 1$ (Figs. 2 and 3). GLP-1 stimulated the release of insulin dose-dependently at 10 and $16.7 \mathrm{mmol} / 1$ glucose. No effect was observed at $2.8 \mathrm{mmol} / 1$ glucose (results not shown):

At $10 \mathrm{mmol} / 1$ glucose (Fig.2), the stimulation reached statistical significance at $2.5 \mathrm{nmol} / 1$ GLP-1 ( $28 \%$ increase), whereas at $0.25 \mathrm{nmol} / 1$ there was only a tendency towards stimulation ( $12 \%$ increase). Near maximal release occurred at $250 \mathrm{nmol} / 1$ with $106 \%$ increase over basal.

In the presence of $16.7 \mathrm{mmol} / 1$ glucose (Fig. 3), the stimulation of insulin release by GLP-1 was similar with regard to percentage increase, ranging from $14 \%$ at $2.5 \mathrm{nmol} / 1$ to $103 \%$ at $2500 \mathrm{nmol} / \mathrm{l}$. Maximal release was $38 \%$ higher than the corresponding value at $10 \mathrm{mmol} / 1$ glucose.

At $25 \mathrm{nmol} / 1$, the incremental insulin release caused by GLP-1 reached 38\% of the glucagon effect in the presence of $16.7 \mathrm{mmol} / 1$ glucose. Half-maximal stimulation was observed for GLP-1 at $25 \mathrm{nmol} / 1$, for glucagon at $8-10 \mathrm{nmol} / 1$. Maximal stimulation occurred with both peptides at $250 \mathrm{nmol} / \mathrm{l}$. GLP-1 reached $63 \%$ of the effect produced by glucagon.

In contrast, GLP-2 did not influence insulin secretion at the same concentrations in the presence of 10 and $16.7 \mathrm{mmol} / 1$ glucose, as summarized in Table 1 , nor at $2.8 \mathrm{mmol} / 1$ glucose (results not shown). At $10 \mathrm{mmol} / 1$ glucose, there was a slight tendency towards inhibition of insulin release (15\% reduction) which did not reach statistical significance nor did it show a dose dependency.

\section{Discussion}

Only few data $[7,8]$ have been reported on biological effects of GLP-1 and GLP-2 which were characterized structurally as nucleotide sequences. The physiological significance of these findings remains unclear.

This study clearly shows that GLP-1 (1-36, C-terminally amidated), with 14 out of 29 homologous residues being the closer glucagon-related peptide (Fig.4), stimulates insulin release from isolated precultured rat pancreatic islets in a dose- and glucose-dependent man- 
Table 1. Effect of glucagon-like peptide-2 (GLP-2) on insulin release in isolated precultured rat pancreatic islets in the presence of $10 \mathrm{mmol} / \mathrm{l}$ and $16.7 \mathrm{mmol} / 1$ glucose

\begin{tabular}{|c|c|c|c|c|c|c|}
\hline & \multicolumn{6}{|c|}{ Glucagon-like peptide-2 (GLP-2) added to the incubated islets (nmol/1) } \\
\hline & - & 0.25 & 2.5 & 25 & 250 & 2500 \\
\hline \multicolumn{7}{|c|}{$\begin{array}{l}\text { Insulin release }\left(\mathrm{mU} \cdot \mathrm{I}^{-1} \cdot 30 \mathrm{~min}^{-1}\right) \\
\text { at }\end{array}$} \\
\hline $\begin{array}{l}10 \mathrm{mmol} / 1 \\
\text { glucose }\end{array}$ & $\begin{array}{l}122 \pm 7 \\
(n=35)\end{array}$ & n.d. & $\begin{array}{l}104 \pm 10 \\
(n=9)\end{array}$ & $\begin{array}{l}105 \pm 9 \\
(n=10)\end{array}$ & $\begin{array}{l}116 \pm 15 \\
(n=7)\end{array}$ & n.d. \\
\hline $\begin{array}{l}16.7 \mathrm{mmol} / 1 \\
\text { glucose }\end{array}$ & $\begin{array}{l}172 \pm 6 \\
(n=66)\end{array}$ & n.d. & $\begin{array}{l}164 \pm 14 \\
(n=9)\end{array}$ & $\begin{array}{l}167 \pm 15 \\
(n=11)\end{array}$ & $\begin{array}{l}158 \pm 11 \\
(n=18)\end{array}$ & $\begin{array}{l}160 \pm 20 \\
(n=20)\end{array}$ \\
\hline
\end{tabular}

Values are expressed as mean \pm SEM, the differences between the groups are not statistically significant. $n$. $d .=$ not determined; $n=$ number of experiments

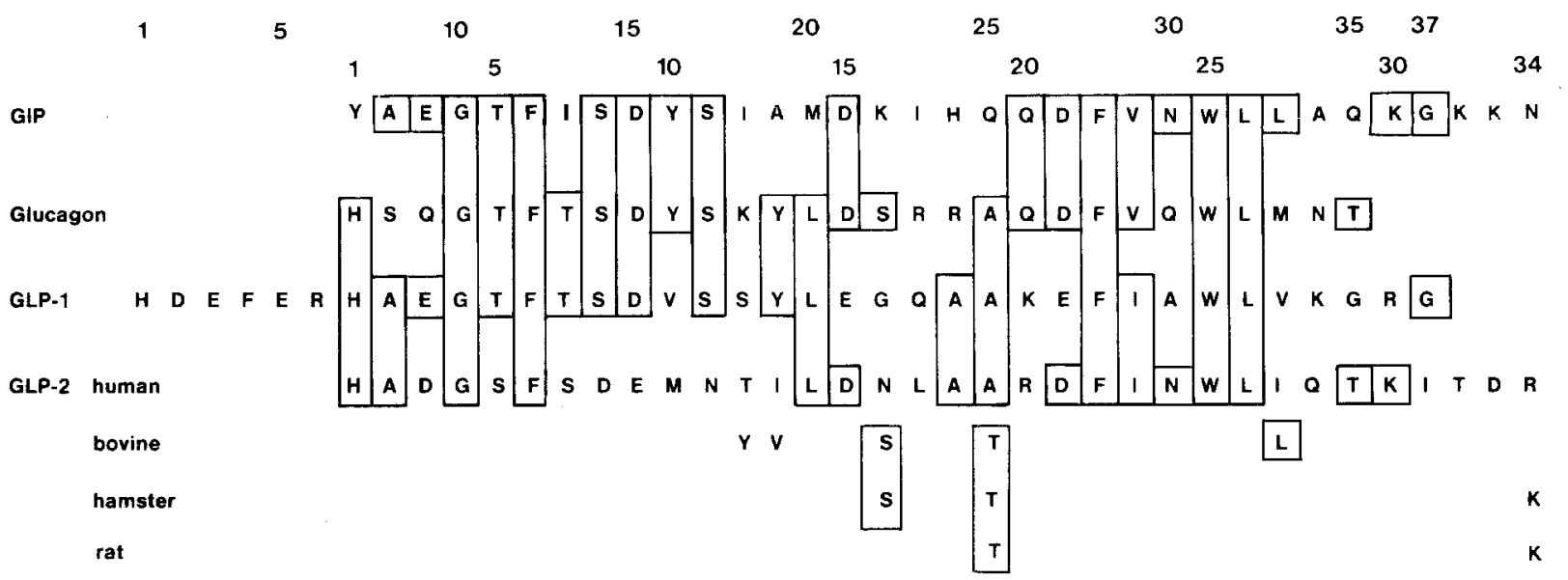

Fig.4. Amino acid sequences of human GIP, residue 1-34 [17], glucagon, glucagon-like peptide-1 (GLP-1) and glucagon-like peptide-2 (GLP-2) [2-5]. The GLP-1 sequence is identical in the human, bovine, hamster and rat glucagon $\mathrm{m}-\mathrm{RNA}$ precursor or gene, respectively; for GLP-2 the species-specific amino acid substitutions are marked

ner. A significant stimulation was observed at 2.5 $\mathrm{nmol} / \mathrm{l}$ in the presence of $10 \mathrm{mmol} / 1$ glucose.

When compared with glucagon under identical incubation conditions, GLP-1 reaches approximately 40 to $60 \%$ of the increment in insulin release over a broad range of concentrations, but only in the presence of high glucose levels. Thus GLP-1 resembles the biological action of gastric inhibitory polypeptide (GIP), also named glucose-dependent insulinotropic polypeptide, which as the best-established "incretin" candidate stimulates insulin release in a strictly glucose-dependent manner [14-16]. Compared with GIP in a similar experimental setting [11], GLP-1 reaches approximately $40 \%$ of the maximal insulin response caused by GIP. Already at a concentration of $0.75-1.0 \mathrm{nmol} / 1$, GIP shows a significant stimulation of insulin release, whereas the effect of GLP-1 starts at $2.5 \mathrm{nmol} / 1$. The overall potency of GLP-1 in stimulating insulin release in this experimental system can be estimated as 30\% compared to GIP.

GLP-1 resembles very closely the glucagon and GIP sequence in the N-terminal half of the molecule (Fig. 4) - 10 out of $15 \mathrm{~N}$-terminal residues are identical in glucagon, 8 out of 11 in GIP, if position 7 of GLP-1 is aligned to position 1 of glucagon and GIP, respectively.
This fact most probably explains the glucagon- and GIP-like action of the peptide on pancreatic islets. However, with regard to the N-terminal extension of GLP-1 beyond the glucagon-like sequence it appears unlikely that the action of GLP-1 is mediated through glucagon receptors [18]; in fact, it has been shown that GLP-1 does not bind to glucagon receptors in the liver [7], so one can speculate that GLP-1 may act on its own or on the GIP-receptor on the pancreatic B-cell which has been recently identified [19].

On the other hand it is yet not excluded that the Nterminally extended peptide of GLP-1 can be cleaved off by a trypsin-like enzyme. Due to its substantially closer sequence homology to glucagon and GIP, it is tempting to predict an even stronger glucagon- and/or GIP-like biological activity of the resulting GLP-1 [7-36] compared with the intact peptide - a hypothesis to be tested in further experiments.

In contrast to our findings, Ghiglione et al. [20] failed to demonstrate a glucagon-like activity of GLP-1 in vivo in rabbits on blood glucose or plasma insulin levels, even at pharmacological doses. Two reasons could explain these negative results: First, due to the lack of interaction with the glucagon receptor in the liver [7] no effect on hepatic gluconeogenesis can be ex- 
pected. Secondly, the authors only investigated the effect of GLP-1 in fasting rabbits, i.e. in the absence of hyperglycemia, and their failure to stimulate insulin release at low glucose levels is in full agreement with our findings. It is also well established that other insulinotropic peptides like GIP do not stimulate insulin release at basal glucose concentrations $[14,16]$.

Whether the fact that the authors used the C-terminally non-amidated form of GLP-1 in their experiments could contribute to the lack of biological activity remains doubtful, since at present no regulatory peptide has been found to possess - Arg- $\mathrm{NH}_{2}$ at the C-terminus. Moreover, for the biological activity within the glucagon family, the $\mathrm{N}$-terminal amino acid residues seem to be essential [18].

Human GLP-2, which possesses 11 out of the 29 amino acid residues of glucagon at homologous positions (Fig. 4), did not augment the secretion of insulin at any of the investigated glucose concentrations. This could be due to the considerably lower degree of sequence homology to glucagon, especially with regard to the N-terminal part of the molecule (residues 4 to 13 ) which is highly conserved within the glucagon family of peptides. In addition, our experiments were carried out with synthetic human GLP-2, which differs from the corresponding recently cloned rat sequence in two residues [5]. A specific biological activity of this peptide has still to be identified.

A recent study of the in vivo posttranslational processing of the glucagon precursor in rat pancreatic islets [21] leads to the suggestion that a tryptic-like cleavage does not occur between the GLP-1 and GLP-2 sequences. Instead it was shown that both sequences are secreted mainly as one "major proglucagon fragment" with very little, if any, GLP-1 and GLP-2 as single entities. These observations raise the question whether this type of posttranslational processing is specific for the pancreatic islet or uniform in other glucagon-containing tissues like the gut. If differential processing occurs within the gut, GLP-1 (1-36) could well qualify as a member of the "incretins" which augment insulin release after an oral glucose load [22]. However, any definite physiological role of these glucagon-like peptides remains to be elucidated.

Acknowledgements. The excellent technical assistance of Ms. K. Bunke, Mrs. E. Rabbe and Ms. M. Cawkwell is gratefully acknowledged. This work was supported by the grants $\mathrm{Cr} 20 / 19-4$ and $\mathrm{Si}$ 313/1-2 from the Deutsche Forschungsgemeinschaft, Bonn.

\section{References}

1. Lund PK, Goodman RH, Dee PC, Habener JF (1982) Pancreatic preproglucagon cDNA contains two glucagon-related coding sequences arranged in tandem. Proc Natl Acad Sci USA 79: 345-349

2. Bell GI, Santerre RF, Mullenbach GT (1983) Hamster preproglucagon contains the sequence of glucagon and two related peptides. Nature 302: 716-718
3. Lopez LC, Frazier ML, Su CJ, Kumar A, Saunders GF (1983) Mammalian pancreatic preproglucagon contains three glucagonrelated peptides. Proc Natl Acad Sci USA 80: 5484-5489

4. Bell GI, Sanchez-Pescador R, Laybourn PJ, Najarian RC (1983) Exon duplication and divergence in the human preproglucagon gene. Nature 304: 368-371

5. Heinrich G, Gros P, Habener JF (1984) Glucagon gene sequence Four of six exons encode separate functional domains of rat preproglucagon. J Biol Chem 259: 14082-14087

6. Uttenthal LO, Ghiglione M, George SK, Bloom SR (1984) Radioimmunoassay for glucagon-like peptide-1: presence in human pancreas and glucagonomas. Diabetologia 27:341 (Abstract)

7. Hossein NM, Gurd RS (1984) Human glucagon-like peptides 1 and 2 activate rat brain adenylate cyclase. FEBS Lett 178:83-86

8. Uttenthal LO, Ghiglione M, George SK, Bloom SR (1984) Effect of glucagon-like peptide-1 (GLP-1) on pancreatic juice output in the rat. Dig Dis Sci 29:91S (Abstract)

9. Lacy PE, Kostianovsky M (1967) Method for the isolation of intact islets of Langerhans from the rat pancreas. Diabetes 16:35-39

10. Siegel EG, Wollheim CB, Renold AE (1980) Evidence for the involvement of $\mathrm{Na} / \mathrm{Ca}$-exchange in glucose-induced insulin release from rat pancreatic islets. J Clin Invest 66:996-1003

11. Siegel EG, Creutzfeldt W (1984) Stimulation of insulin release and cyclic AMP content by physiological levels of GIP in isolated islets. Europ J Clin Invest 14II: 283 (Abstract)

12. Melani F, Ditschuneit H, Bartelt KM, Friedrich H, Pfeiffer EF (1965) Über die radioimmunologische Bestimmung von Insulin im Blut. Klin Wochenschr 43: 1000-1007

13. Holm S (1979) A simple sequentially rejective multiple test procedure. Scand J Statist 6: 65-70

14. Schauder P, Brown JC, Frerichs H, Creutzfeldt W (1975) Gastric inhibitory polypeptide: effect on glucose-induced insulin release from isolated rat pancreatic islets in vitro. Diabetologia 11: 483-484

15. Dupre J, Ross SA, Watson D, Brown JC (1973) Stimulation of insulin secretion by gastric inhibitory polypeptide in man. J Clin Endocrinol Metabol 37: 826-829

16. Andersen DK, Elahi D, Brown JC, Tobin JD, Andres R (1978) Oral glucose augmentation of insulin secretion. Interaction of gastric inhibitory polypeptide with ambient glucose and insulin levels. J Clin Invest 62:152-161

17. Moody AJ, Thim L, Valverde I (1984) The isolation and sequencing of human gastric inhibitory polypeptide (GIP). FEBS Lett 172: $142-148$

18. Holst JJ (1983) Gut glucagon, enteroglucagon, gut glucagon-like immunoreactivity, glicentin - current status. Gastroenterology 84: 1602-1613

19. Maletti M, Portha B, Carlquist M, Kergoat M, Laburthe M, Marie JC, Rosselin G (1984) Evidence for and characterization of specific high affinity binding sites for the gastric inhibitory polypeptide in pancreatic $\beta$-cells. Endocrinology 115: 1324-1331

20. Ghiglione M, Uttenthal LO, George SK, Bloom SR (1984) How glucagon-like is glucagon-like peptide-1? Diabetologia 27: 599-600

21. Patzelt C, Schiltz E (1984) Conversion of proglucagon in pancreatic alpha cells: The major endproducts are glucagon and a single peptide, the major proglucagon fragment, that contains two glucagon-like sequences. Proc Natl Acad Sci USA 81: 5007-5011

22. Creutzfeldt W (1979) The incretin concept today. Diabetologia 16: $75-85$

Received: 6 May 1985

and in revised form: 17 July 1985

Dr. Wolfgang E. Schmidt

Medizinische Universitäts-Klinik

Abteilung Gastroenterologie/Stoffwechsel

Robert-Koch-Straße 40

D-3400 Göttingen

FRG 